\title{
Geniposide attenuates epilepsy symptoms in a mouse model through the PI3K/Akt/GSK-3ß signaling pathway
}

\author{
HONGTAO WEI, GUANGHUI DUAN, JIANXUN HE, QINGLONG MENG, \\ YUXIAN LIU, WANQIANG CHEN and YONGPENG MENG
}

Department of Neurosurgery, The Second People's Hospital of Gansu Province, Lanzhou, Gansu 730000, P.R. China

Received January 30, 2016; Accepted October 18, 2017

DOI: $10.3892 /$ etm.2017.5512

\begin{abstract}
Previous reports on the pharmacological actions of geniposide have indicated that it has anti-asthmatic, anti-inflammatory and analgesic effects in the liver and gallbladder, and therapeutic effects in neurological, cardiovascular and cerebrovascular diseases. The results of the current study demonstrate that geniposide attenuates epilepsy in a mouse model through the phosphoinositide 3-kinase (PI3K)/protein kinase B (Akt)/glycogen synthase kinase-3 $\beta$ (GSK-3 $\beta$ ) signaling pathway. A mouse model of epilepsy was induced by maximal electric shock $(50 \mathrm{~mA}, 50 \mathrm{~Hz}, 1 \mathrm{sec})$. Epilepsy mice were intragastrically administered with $0,5,10$ or $20 \mathrm{mg} / \mathrm{kg}$ geniposide. Geniposide significantly reduced the incidence and significantly increased the latency of clonic seizures in epileptic mice compared with non-treated epileptic mice (both $\mathrm{P}<0.01)$. Geniposide treatment significantly inhibited cyclooxygenase-2 mRNA expression in epilepsy mice $(\mathrm{P}<0.01)$. Furthermore, geniposide significantly suppressed the protein expression of activator protein 1 , increased the activation of Akt and increased the protein expression of GSK-3 $\beta$ and PI3K in epilepsy mice (all $\mathrm{P}<0.01$ ). These results suggest that geniposide attenuates epilepsy in mice through the PI3K/Akt/GSK-3 $\beta$ signaling pathway.
\end{abstract}

\section{Introduction}

The primary goal when treating epilepsy is to prevent seizures with minimal side effects to increase patients; quality of life $(1,2)$. In China, there are $\sim 9$ million people with epilepsy, 6 million of which are diagnosed with active epilepsy. Each year, 0.4 million new cases are reported (3). Mortality risk for epilepsy patients is 2-3 times higher than that of the normal population. Although multiple drug therapies exist for

Correspondence to: Dr Hongtao Wei, Department of Neurosurgery, The Second People's Hospital of Gansu Province, 1 Hezhengxi Road, Lanzhou, Gansu 730000, P.R. China

E-mail: wazhi58975444@126.com

Key words: geniposide, epilepsy, inflammation, protein kinase B, glycogen synthase kinase- $3 \beta$ epilepsy, anti-epilepsy drugs are not effective for one-third of patients (4). These drugs only try to control the symptoms of epilepsy, and do not affect the occurrence or pathological processes of the disease (5).

Previous studies have indicated that autoimmune disorders, such as systemic lupus erythematosus and vasculitis, are important causes of epilepsy (6). Invasion of activated microglial cells, inflammatory media and lymphocytes in infant brains can trigger autoimmune disorders, which can lead to catastrophic epilepsy in children (7). In addition, patients with autoimmune diseases of the central nervous system or $\mathrm{N}$-methyl-D-aspartate receptor encephalitis are at a high risk of epilepsy (8). Inflammation is a key factor in the occurrence and recurrence of epilepsy and has been associated with its pathological severity (9).

Epilepsy is a disease of the nervous system. Repeated attacks can result in brain neuron injuries or patient fatality (10). The phosphatidylinositol-3-kinase (PI3K)/protein kinase B (Akt) signal transduction pathway is a key intra-cellular survival pathway (11). Whether cell apoptosis occurs or not largely depends on activation of the PI3K/Akt signal transduction pathway and a cascade of downstream signals (12).

Gardenia jasminoides Ellis is principally grown in Zhejiang, Fujian, Jiangxi, Hunan and Guangdong in China. Geniposide is derived from G. jasminoides Ellis and previous studies have suggested that it can be used to reduce fever, acute icteric hepatitis, cystitis and upper gastrointestinal hemorrhage (13-15). The present study aimed to investigate whether geniposide treatment could reduce epilepsy symptoms in a mouse model through the PI3K/Akt/glycogen synthase kinase-3 $\beta$ (GSK-3 $\beta$ ) signaling pathway.

\section{Materials and methods}

Animals. All experimental protocols were performed in accordance with the guidelines of the Institutional Animal Care and Use Committee of The Second People's Hospital of Gansu Province (Lanzhou, China). Ethical approval was granted by the Ethics Committee of the Second People's Hospital of Gansu Province. A total of $38 \mathrm{C} 57 \mathrm{Bl} / 6$ mice aged 11-12 weeks (20-23 g, male) obtained from Medical Experimental Center of Lanzhou University (Lanzhou, China) were used in the present study and housed in an animal laboratory (temperature, $22 \pm 1^{\circ} \mathrm{C}$; humidity, $55 \pm 5 \%$ ) on a $12 \mathrm{~h}$ light/dark cycle. 
Mouse model of epilepsy and grouping. A mouse model of epilepsy was induced by maximal electric shock $(50 \mathrm{~mA}$, $50 \mathrm{~Hz}, 1 \mathrm{sec}$ ) through ear clip electrodes using a stimulator apparatus, as previously described (16). Mice were randomly assigned into the following groups: Sham $(10 \mathrm{ml} / \mathrm{kg}$ saline, $\mathrm{n}=6)$, epilepsy model $(10 \mathrm{ml} / \mathrm{kg}$ saline, $\mathrm{n}=8), 5$ Gen group $(5 \mathrm{mg} / \mathrm{kg}$ geniposide, $\mathrm{n}=8), 10 \mathrm{Gen}$ group $(10 \mathrm{mg} / \mathrm{kg}$ geniposide, $\mathrm{n}=8)$ and $20 \mathrm{Gen}$ group $(20 \mathrm{mg} / \mathrm{kg}$ geniposide, $\mathrm{n}=8)$. Saline and geniposide were administered intragastrically. Geniposide was purchased from Sigma-Aldrich (Merck KGaA, Darmstadt, Germany) and its chemical structure is shown in Fig. 1.

Stereotaxic surgery and kindling procedure. Mice were anesthetized with intravenous injection of $60 \mathrm{mg} / \mathrm{kg}$ ketamine and $10 \mathrm{mg} / \mathrm{kg}$ xylazine (Sigma-Aldrich; Merck KGaA) and then stereotaxically implanted with bipolar stimulating and monopolar recording stainless-steel Teflon-coated electrodes (A-M Systems, Sequim, WA, USA; -2.5 mm from bregma, $4.8 \mathrm{~mm}$ lateral and $7.4 \mathrm{~mm}$ ventral to dura). An additional electrode was attached to a skull screw and fixed to the left cortical surface with dental acrylic. At four weeks after treatment with geniposide, the after discharge (AD) threshold was recorded in the amygdala using a 2 -sec stimulus $(100 \mathrm{~Hz}$, $1 \mathrm{msec} /$ pulse). Stimulation was initially delivered at $50 \mu \mathrm{A}$ with 5-min intervals. Then stimulus intensity was increased by $50 \mu \mathrm{A}$, which was delivered until at least $5 \mathrm{sec}$ of $\mathrm{AD}$ threshold was recorded. AD threshold was measured once a day until three consecutive stage 5 seizures were observed. The seizure stages were defined as follows: Stage 1, facial clonus; stage 2, head nodding; stage 3 , forelimb clonus; stage 4 , rearing and bilateral forelimb clonus; stage 5 , rearing, loss of balance and falling (17). In the sham group, mice were anesthetized as above and no surgical procedures were performed. Following induction of the AD model, all mice were immediately weighed and were subsequently weighed at weeks 1, 2, 3 and 4 .

Clonic seizures or generalized seizures. Mice that appeared less active and exhibited fremitus, mutation, scratching, face twitching or disequilibrium were considered to experience clonic seizures. Mice were scored as follows; 0 seizures, stage 1; 1 seizure, stage 2; 2 seizures, stage 3; 3 seizures, stage $4 ;>3$ seizures, stage 5 . The incidence $(\%)$ of clonic seizures was calculated using the following formula: (number of clonic seizures/total number of mice) $x 100$. The number of mice exhibiting each seizure stage (1-5 stages) was expressed as S. The incidence (\%) of generalized seizures as calculated using the following formula: (S/total number $\times 5) \times 100$.

Reverse transcription-quantitative polymerase chain reaction $(R T-q P C R)$. Following 4 weeks of treatment with geniposide, mice were sacrificed by decapitation under anesthetization (intravenous injection of $35 \mathrm{mg} / \mathrm{kg}$ pentobarbital sodium (Sigma-Aldrich; Merck KGaA). Total RNA was extracted from blood using an Easy Total RNA Extraction kit (Tiangen Biotech Co., Ltd., Beijing, China). Total RNA (1 $\mu \mathrm{g})$ was converted to cDNA using the ReverTra ACE- $\alpha$-RNAeasy kit (Toyobo Co., Ltd., Osaka, Japan). The Bio-Rad CFX96 Real-Time system (Bio-Rad Laboratories, Inc., Hercules, CA,

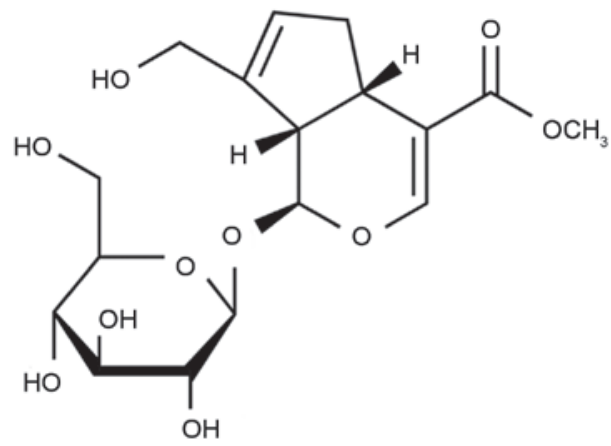

Figure 1. Chemical structure of geniposide.

USA) was performed to analyze the mRNA expression of inducible nitric oxide synthase (iNOS) and cyclooxygenase-2 (COX-2). The primers used were as follows: iNOS forward, 5'-GCTCGCTTTGCCACGGACGA-3' and reverse, 5'-AAG GCAGCGGGCACATGCAA-3'; COX-2 forward, 5'-GGG CTCAGCCAGGCAGCAAAT-3' and reverse, 5'-GCACTG TGTTTGGGGTGGGCT-3'; $\beta$-actin forward, 5'-CTGTCC CTGTATGCCTCTG-3' and reverse, 5'-ATGTCACGCACG ATTTCC-3'. A custom PCR master mix (Tiangen Biotech Co., Ltd., Beijing, China) was used. The reaction conditions were as follows: $95^{\circ} \mathrm{C}$ for $45 \mathrm{sec}$, followed by 40 cycles of $95^{\circ} \mathrm{C}$ for $30 \mathrm{sec}, 55^{\circ} \mathrm{C}$ for $40 \mathrm{sec}$ and $72^{\circ} \mathrm{C}$ for $30 \mathrm{sec}$.

Western blot analysis. Hippocampus tissue samples were homogenized using radioimmunoprecipitation assay buffer (Beyotime Institute of Biotechnology) and protease/phosphatase inhibitor cocktail (EMD Millipore, Billerica, MA, USA). The cell lysate was centrifuged at $12,000 \mathrm{x} g$ for $10 \mathrm{~min}$ at $4^{\circ} \mathrm{C}$ and the supernatant was collected. Protein concentrations were determined using a bicinchoninic acid protein assay kit (Beyotime Institute of Biotechnology). Proteins $(20 \mu \mathrm{g})$ were separated by $8-12 \%$ SDS-PAGE and transferred to polyvinylidene difluoride membranes. The membranes were blocked with $5 \%$ bovine serum albumin (NanJing SunShine Biotechnology Co., Ltd., Nanjing, China) for $1 \mathrm{~h}$ at room temperature and probed with anti-AP-1 $(1: 3,000)$, anti-PI3K (sc-7174; 1:2,000), anti-Akt (sc-8312; 1:2,000) and anti-phosphorylated (p)-Akt (sc-7985-R; 1:5,000; all Genetimes Technology, Inc., Shanghai, China), anti-GSK-3 $\beta$ (sc-7879; 1:2,000; Santa Cruz Biotechnology, Inc., Dallas, TX, USA) and anti- $\beta$-actin (sc-7210; 1:5,000; Genetimes Technology, Inc.) overnight at $4^{\circ} \mathrm{C}$. The membranes were then washed with TBS with Tween-20 and incubated with horseradish peroxidase-conjugated secondary antibody (sc-2004; 1:5,000; Santa Cruz Biotechnology, Inc.) at $37^{\circ} \mathrm{C}$ for $1 \mathrm{~h}$. The results were visualized using an enhanced chemiluminescence substrate reagent kit (EMD Millipore). Protein expression was measured using the ChemiDoc ${ }^{\mathrm{TM}}$ XRS luminescent image analyzer and Image Lab version 2.0.1 software (both Bio-Rad Laboratories, Inc.).

Statistical analysis. All values are presented as the mean \pm standard error of the mean. Statistical analysis was performed using SPSS 17.0 software (SPSS, Inc., Chicago, IL, USA) and the two-tailed Student's t-test or one-way analysis 


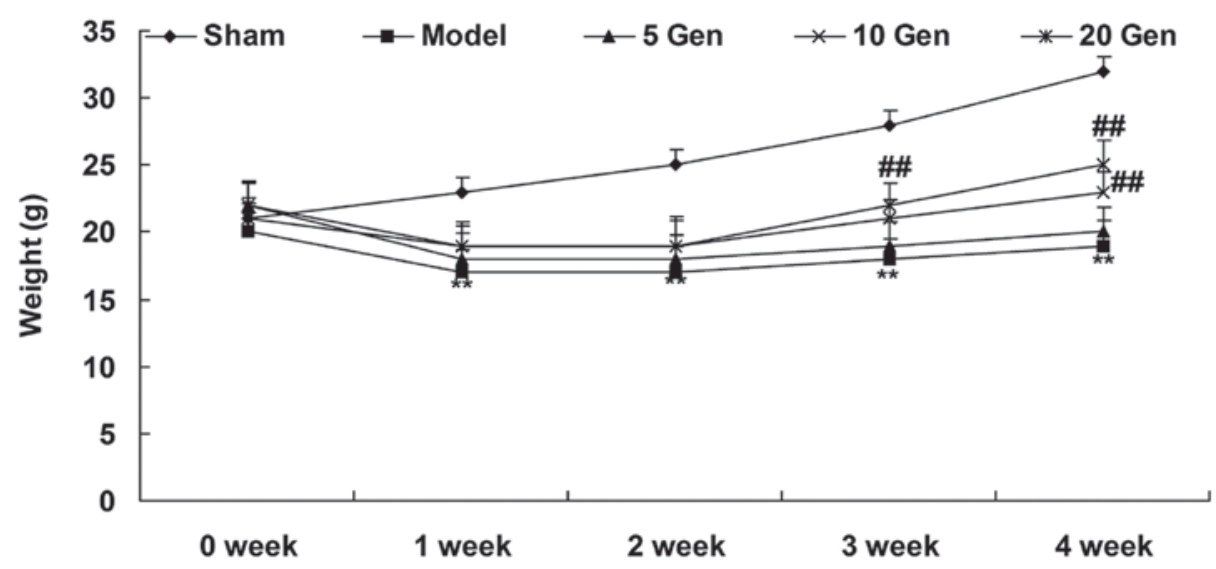

Figure 2. Weight of epileptic mice and controls throughout experimental period. ${ }^{* *} \mathrm{P}<0.01$ vs. Sham; ${ }^{* \#} \mathrm{P}<0.01$ vs. Model. Sham, sham group; Model, epilepsy model control group; $5 \mathrm{Gen}, 5 \mathrm{mg} / \mathrm{kg}$ geniposide group; $10 \mathrm{Gen}, 10 \mathrm{mg} / \mathrm{kg}$ geniposide group; $20 \mathrm{Gen}, 20 \mathrm{mg} / \mathrm{kg}$ geniposide group.

A

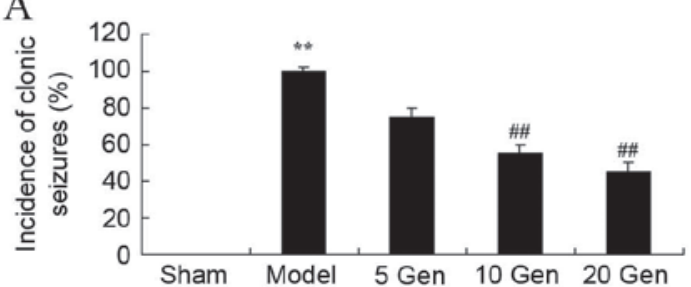

B

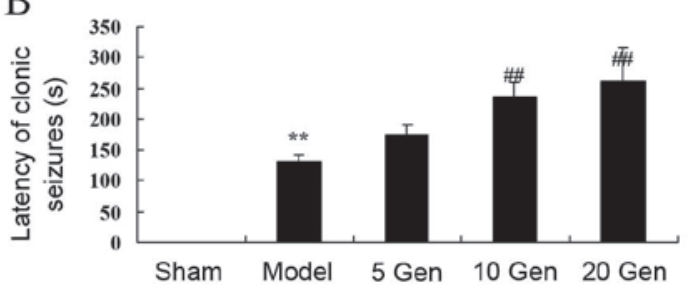

Figure 3. Effect of geniposide treatment on clonic seizures in mouse epilepsy. (A) Incidence and (B) latency of clonic seizures were recorded in epileptic mice. ${ }^{* *} \mathrm{P}<0.01$ vs. Sham; ${ }^{\# \#} \mathrm{P}<0.01$ vs. Model. Sham, sham group; Model, epilepsy model control group; $5 \mathrm{Gen}, 5 \mathrm{mg} / \mathrm{kg}$ geniposide group; $10 \mathrm{Gen}, 10 \mathrm{mg} / \mathrm{kg}$ geniposide group; $20 \mathrm{Gen}, 20 \mathrm{mg} / \mathrm{kg}$ geniposide group.

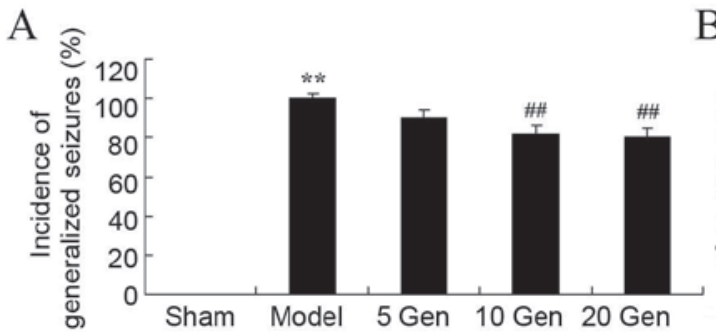

B

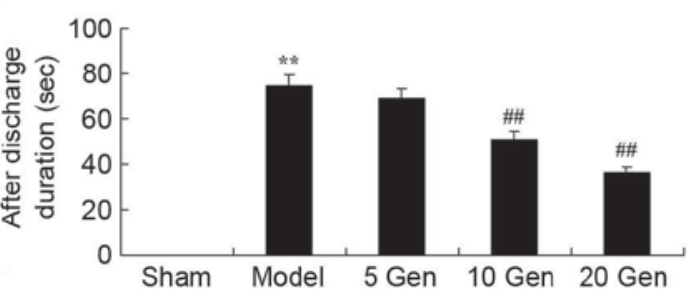

Figure 4. Effect of geniposide treatment on generalized seizures in mouse epilepsy. (A) Incidence of generalized seizures before and (B) after discharge duration were recorded in epileptic mice. ${ }^{* *} \mathrm{P}<0.01$ vs. Sham; ${ }^{\# /} \mathrm{P}<0.01$ vs. Model. Sham, sham group; Model, epilepsy model control group; $5 \mathrm{Gen}, 5 \mathrm{mg} / \mathrm{kg}$ geniposide group; $10 \mathrm{Gen}, 10 \mathrm{mg} / \mathrm{kg}$ geniposide group; $20 \mathrm{Gen}, 20 \mathrm{mg} / \mathrm{kg}$ geniposide group.

of variance. $\mathrm{P}<0.05$ was considered to indicate a statistically significant difference.

\section{Results}

Effect of epilepsy and geniposide treatment on mouse weight. At one week after geniposide treatment, the epilepsy model mice weighed less than the Sham group $(\mathrm{P}<0.01 ;$ Fig. 2). The weights of the epilepsy model mice increased from week 2 to 4, but remained lower than the Sham group throughout the experimental period $(\mathrm{P}<0.01$; Fig. 2).

Effect of geniposide on clonic seizures in mouse epilepsy. In the current study, the effects of geniposide treatment on the incidence and latency of clonic seizures in mice epilepsy were evaluated. The incidence of clonic seizures was significantly higher in the epilepsy model control group compared with the sham group $(\mathrm{P}<0.01$; Fig. 3A). The latency of clonic seizures was significantly reduced in the epilepsy model control group compared with the sham group $(\mathrm{P}<0.01$; Fig. $3 \mathrm{~B})$. However, geniposide treatment $(10 \mathrm{or} 20 \mathrm{mg} / \mathrm{kg})$ significantly reduced the incidence and significantly increased the latency of clonic seizures compared with the epileptic model control group (both $\mathrm{P}<0.01$; Fig. 3A and B).

Effect of geniposide on generalized seizures in mouse epilepsy. The epileptic model control group showed a significant increase in the incidence of generalized seizures compared with the sham group $(\mathrm{P}<0.01$; Fig. $4 \mathrm{~A})$. A significant reduction was observed in the incidence of generalized seizures 
after geniposide treatment. However, there was a significant increase in $\mathrm{AD}$ duration in the epilepsy model control group compared with the sham group $(\mathrm{P}<0.01$; Fig. 4B) and geniposide treatment (10 or $20 \mathrm{mg} / \mathrm{kg}$ ) significantly attenuated AD duration compared with the epilepsy model control group $(\mathrm{P}<0.01$; Fig. 4B).

Effect of geniposide on iNOS mRNA expression in mouse epilepsy. The level of iNOS mRNA expression in epileptic mice was analyzed using RT-qPCR. As shown in Fig. 5, there was no significant difference in iNOS mRNA expression between the sham group and the epileptic model control, or between the epileptic model control and the geniposide-treated epileptic groups.

Effect of geniposide on COX-2 mRNA expression in mouse epilepsy. The level of COX-2 mRNA expression in epileptic mice was analyzed using RT-qPCR. As shown in Fig. 6, COX-2 mRNA expression was significantly higher in the epilepsy model control group compared with the sham group $(\mathrm{P}<0.01)$. Furthermore, treatment with geniposide $(10$ or $20 \mathrm{mg} / \mathrm{kg})$ significantly inhibited the epilepsy-induced COX-2 mRNA expression compared with the epileptic model control $(\mathrm{P}<0.01)$.

Effect of geniposide on AP-1 protein expression in mouse epilepsy. The level of AP-1 protein expression was evaluated by western blot analysis. As shown in Fig. 7, AP-1 protein expression was significantly higher in the epilepsy model control group compared with the sham group $(\mathrm{P}<0.01)$. Furthermore, treatment with geniposide (10 or $20 \mathrm{mg} / \mathrm{kg}$ ) significantly suppressed AP-1 protein expression compared with the epileptic model control $(\mathrm{P}<0.01)$.

Effect of geniposide on GSK-3 $\beta$ protein expression in mouse epilepsy. The level of GSK-3 $\beta$ protein expression was evaluated by western blot analysis. As shown in Fig. 8 , GSK-3 $\beta$ protein expression was significantly lower in the epilepsy model control group compared with the sham group $(\mathrm{P}<0.01)$. Furthermore, geniposide treatment (10 or $20 \mathrm{mg} / \mathrm{kg}$ ) significantly promoted GSK-3 $\beta$ protein expression compared with the epileptic model control $(\mathrm{P}<0.01)$.

Effect of geniposide on PI3K protein expression in mouse epilepsy. The level of $\mathrm{PI} 3 \mathrm{~K}$ protein expression was evaluated by western blot analysis. As shown in Fig. 9, PI3K protein expression was significantly lower in the epilepsy model control group compared with the sham group $(\mathrm{P}<0.01)$. Furthermore, geniposide treatment (10 or $20 \mathrm{mg} / \mathrm{kg}$ ) significantly promoted PI3K protein expression compared with the epileptic model control $(\mathrm{P}<0.01)$.

Effect of geniposide on Akt protein expression in mouse epilepsy. In order to investigate the anti-apoptosis effects of geniposide on Akt protein expression in mice epilepsy, Akt and p-Akt protein expression was evaluated by western blot analysis (Fig. 10). The p-Akt/Akt rate was significantly reduced in the epilepsy model control group compared with the sham group $(\mathrm{P}<0.01)$. Furthermore, treatment with geniposide (10 or $20 \mathrm{mg} / \mathrm{kg}$ ) significantly increased the $\mathrm{p}$-Akt/Akt rate compared with the epileptic model control $(\mathrm{P}<0.01)$.

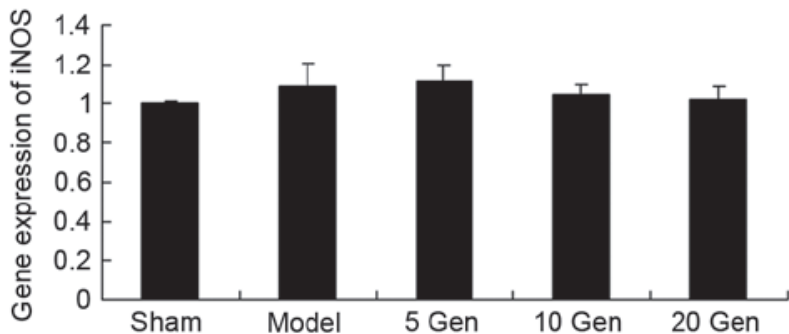

Figure 5. Effect of geniposide treatment on iNOS mRNA expression in mouse epilepsy. Sham, sham group; Model, epilepsy model control group; $5 \mathrm{Gen}, 5 \mathrm{mg} / \mathrm{kg}$ geniposide group; $10 \mathrm{Gen}, 10 \mathrm{mg} / \mathrm{kg}$ geniposide group; $20 \mathrm{Gen}, 20 \mathrm{mg} / \mathrm{kg}$ geniposide group; iNOS, induced nitric oxide synthase.

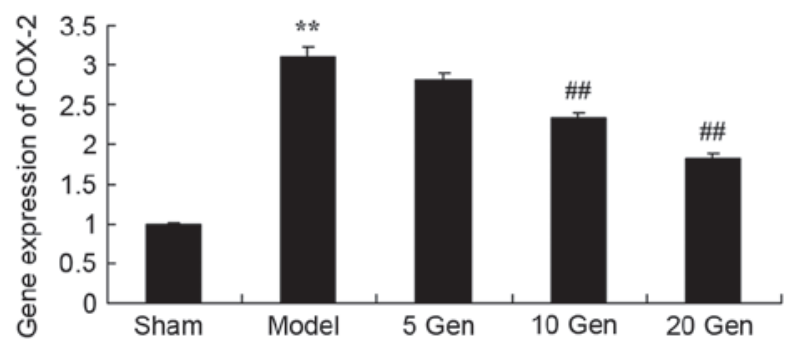

Figure 6. Effect of geniposide treatment on COX-2 mRNA expression in mouse epilepsy. ${ }^{* *} \mathrm{P}<0.01$ vs. Sham; ${ }^{\#} \mathrm{P}<0.01$ vs. Model. Sham, sham group; Model, epilepsy model control group; $5 \mathrm{Gen}, 5 \mathrm{mg} / \mathrm{kg}$ geniposide group; $10 \mathrm{Gen}, 10 \mathrm{mg} / \mathrm{kg}$ geniposide group; $20 \mathrm{Gen}, 20 \mathrm{mg} / \mathrm{kg}$ geniposide group; COX-2, cyclooxygenase-2.

\section{A}
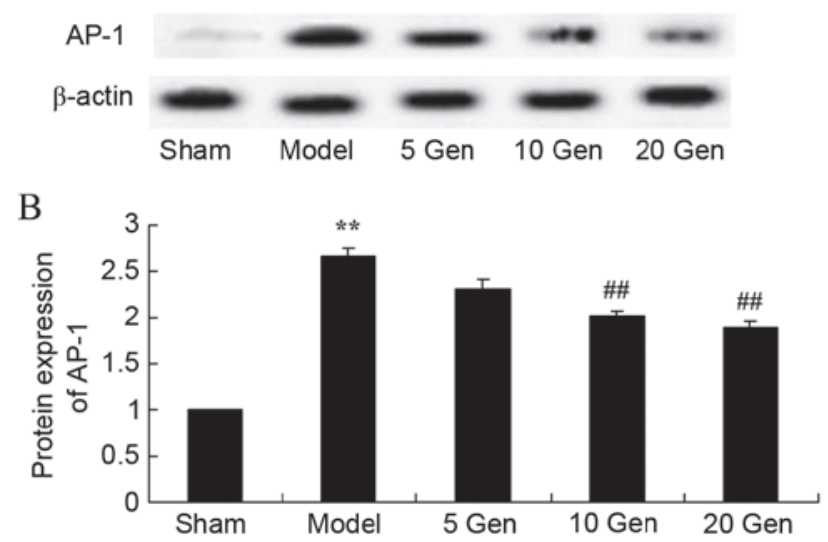

Figure 7. Effect of geniposide treatment on AP-1 protein expression in mouse epilepsy. (A) Western blot analysis and (B) quantification of AP-1 protein expression in mouse epilepsy, with or without geniposide treatment. ${ }^{* *} \mathrm{P}<0.01$ vs. Sham; ${ }^{\# \#} \mathrm{P}<0.01$ vs. Model. Sham, sham group; Model, epilepsy model control group; $5 \mathrm{Gen}, 5 \mathrm{mg} / \mathrm{kg}$ geniposide group; $10 \mathrm{Gen}, 10 \mathrm{mg} / \mathrm{kg}$ geniposide group; $20 \mathrm{Gen}$, $20 \mathrm{mg} / \mathrm{kg}$ geniposide group; AP-1, activator protein 1.

\section{Discussion}

As a paroxysmal minimal brain dysfunction, epilepsy is characterized by acute spasms. The morbidity rate of epilepsy is 24-53/100,000 in developed countries and 77-114/100,000 in developing countries (18). The morbidity rate in children is $151 / 10,000$ (19). To the best of our knowledge, the present study is the first to demonstrate a protective effect of geniposide in mouse epilepsy, through a reduction in clonic. 
A

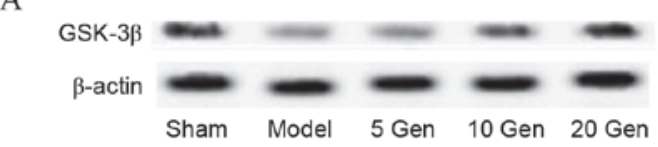

B

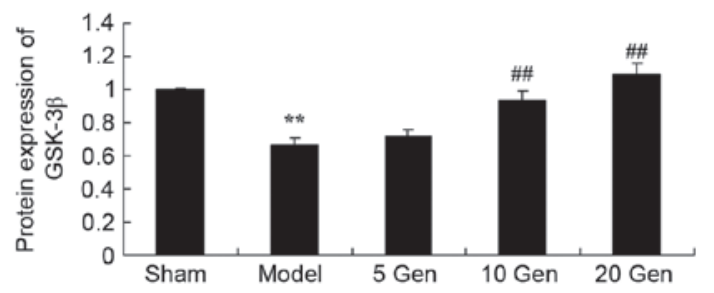

Figure 8. Effect of geniposide treatment on GSK-3 $\beta$ protein expression in mouse epilepsy. (A) Western blot analysis and (B) quantification of GSK-3 $\beta$ protein expression in mouse epilepsy, with or without geniposide treatment. ${ }^{* *} \mathrm{P}<0.01$ vs. Sham; ${ }^{\# \#} \mathrm{P}<0.01$ vs. Model. Sham, sham group; Model, epilepsy model control group; $5 \mathrm{Gen}, 5 \mathrm{mg} / \mathrm{kg}$ geniposide group; $10 \mathrm{Gen}, 10 \mathrm{mg} / \mathrm{kg}$ geniposide group; $20 \mathrm{Gen}, 20 \mathrm{mg} / \mathrm{kg}$ geniposide group; GSK-3 $\beta$, glycogen synthase kinase- $3 \beta$.

A

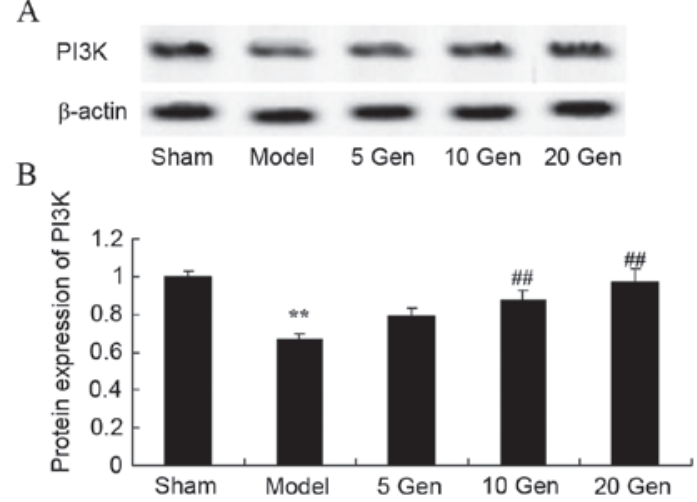

Figure 9. Effect of geniposide treatment on PI3K protein expression in mouse epilepsy. (A) Western blot analysis and (B) quantification of PI3K protein expression in mouse epilepsy, with or without geniposide treatment. ${ }^{* *} \mathrm{P}<0.01$ vs. Sham; ${ }^{\# \#} \mathrm{P}<0.01$ vs. Model. Sham, sham group; Model, epilepsy model control group; $5 \mathrm{Gen}, 5 \mathrm{mg} / \mathrm{kg}$ geniposide group; $10 \mathrm{Gen}, 10 \mathrm{mg} / \mathrm{kg}$ geniposide group; $20 \mathrm{Gen}$, $20 \mathrm{mg} / \mathrm{kg}$ geniposide group; PI3K, phosphoinositide 3-kinase.

A

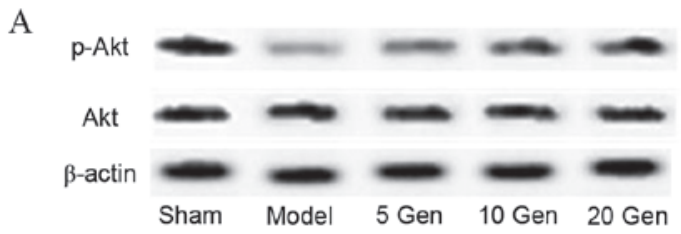

B

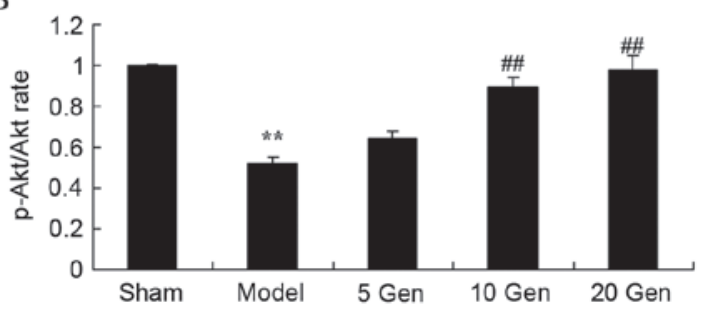

Figure 10. Effect of geniposide treatment on Akt protein expression in mouse epilepsy. (A) Western blot analysis of Akt and p-Akt protein expression. (B) Quantification of Akt and p-Akt protein expression, expressed as p-Akt/Akt rate. ${ }^{* *} \mathrm{P}<0.01$ vs. Sham; ${ }^{\# \#} \mathrm{P}<0.01$ vs. Model. Sham, sham group; Model, epilepsy model control group; $5 \mathrm{Gen}, 5 \mathrm{mg} / \mathrm{kg}$ geniposide group; $10 \mathrm{Gen}, 10 \mathrm{mg} / \mathrm{kg}$ geniposide group; $20 \mathrm{Gen}, 20 \mathrm{mg} / \mathrm{kg}$ geniposide group; Akt, protein kinase B; p-Akt, phosphorylated Akt.
Nitric oxide (NO) has a dual function of neuroprotection and neurovirulence in the central nervous system (20). Previous results indicated that NO and NO synthase were significantly elevated in the brains of epilepsy patients, which may be related to cell damages after an attack of epilepsy (21). Previous research also confirmed that cell apoptosis after epilepsy was related to overexpression of NO, which demonstrated that iNOS was more closely related with apoptosis (22). Another study demonstrated that a selective iNOS inhibitor could significantly reduce the expression of caspase-3 (23). The results of the current study suggested that geniposide treatment did not significantly affect iNOS mRNA expression in mouse epilepsy. Zhang et al proposed that geniposide inhibits LPS-induced iNOS expression in N9 microglial cells (24).

COX-2 participates in pathological processes such as inflammation and tumor invasion (25). It has been found that multiple stimuli, including cytokines, hormones, ischemia, hypoxemia, epilepsy and phorbol ester can increase the expression of COX-2 (26). In the majority of cells, COX-2 expression can increase rapidly after an attack of epilepsy or cerebral ischemia and can be inhibited by corticosteroids (27). Therefore, it is dynamically regulated. The results of the current study indicated that geniposide reduces COX-2 mRNA expression in mouse epilepsy. Shi et al reported that geniposide suppresses lipopolysaccharide (LPS)-induced iNOS and COX-2 signaling pathways in macrophages (28).

Previous results have indicated that activated AP-1 is a key transcription factor for inflammatory responses and causes severe inflammatory reactions, disturbs neural pathways, influences nerve conduction and impairs tissues (29). A previous study confirmed that the majority of inflammatory mediators are regulated by transcription factors (29). AP-1 may regulate the expression of inflammatory factors and therefore affect the severity of inflammation and the efficacy of therapeutic strategies (29). AP-1 is a homodimer or heterodimer of c-fos and c-jun. Under basal conditions, the concentration and activity of AP-1 are relatively low (30). When cells are stimulated, AP-1 expression increases (30). The results of the current study indicated that geniposide reduces AP-1 protein expression in mouse epilepsy. Shi et al demonstrated that geniposide suppresses the LPS-induced inflammatory cytokine, prostaglandin E2, and NO through inhibition of AP-1 signaling pathways in macrophages (28).

Akt has been demonstrated to be the direct downstream substrate of PI3K (10). As an inhibitor of PI3K can block the activation of Akt, the activation status of PI3K/Akt pathways can be predicted by observing the expression of p-Akt (10). Previous results have suggested that apoptosis plays an important role in cerebral neuron death after epilepsy (31). As a key component of survival signal, Akt is necessary to cellular survival triggered by growth factors, extra-cellular matrix and other stimulus (31). Activated Akt is a cellular survival factor that can help cells escape from programmed cell death by inactivating multiple effector molecules of apoptosis (32). In the present study, it was demonstrated that geniposide induces PI3K/Akt pathways in mice epilepsy. Guo et al reported that geniposide increases insulin secretion in pancreatic $\beta$-cells through involvement of PI3K (33). Park et al suggested that geniposide may suppress 
transforming growth factor- $\beta 1 /$ epithelial-mesenchymal transition and activate Akt signaling pathways in AML12 hepatocytes (34).

Composed of 23 sub-units of GSK-3 $\alpha$ and GSK-3 $\beta$, GSK-3 is a serine/threonine kinase (35). It is a key component of multiple signal transduction pathways and is closely associated with cell differentiation, proliferation and apoptosis, and diseases such as diabetes, cancer and neurodegenerative disease (36). GSK-3 $\beta$ has been indicated to be extensively distributed in rat cerebral tissues, with high levels of expression in the hippocampus (36). A previous study on epilepsy reported that GSK-3 $\beta$ could hyperphosphorylate microtubule-associated protein tau. P-tau proteins are key components of neurofibrillary tangles in epilepsy (35). Previous research has also reported that excessive $\mathrm{p}$-tau protein is related to cognitive impairment in Alzheimer's disease (37). In the present study, it was demonstrated that geniposide attenuates GSK-3 $\beta$ protein expression in mice epilepsy. Collectively, Zhang et al reported that insulin-deficient APP/PS1 transgenic and GSK-3 $\beta$ protein expression in mouse model of Alzheimer's disease (38).

In conclusion, the present study demonstrated that geniposide attenuates clonic seizures and generalized seizures in mice epilepsy. Furthermore, the current results indicate that geniposide reduces COX-2 and AP-1 expression, and that the underlying mechanism of geniposide involves the PI3K/Akt/GSK-3 $\beta$ signaling pathway to adjust neurocyte apoptosis. These findings may be beneficial for developing effective treatment strategies for epilepsy.

\section{Acknowledgements}

The present study was supported by the Health Industry Scientific Research Projects in Gansu Province (grant no. GSWST2012-07).

\section{References}

1. Velez FF, Bond TC, Anastassopoulos KP, Wang X, Sousa R, Blum D and Cramer JA: Impact of seizure frequency reduction on health-related quality of life among clinical trial subjects with refractory partial-onset seizures: A pooled analysis of phase III clinical trials of eslicarbazepine acetate. Epilepsy Behav 68: 203-207, 2017.

2. Anderson WS, Kossoff EH, Bergey GK and Jallo GI: Implantation of a responsive neurostimulator device in patients with refractory epilepsy. Neurosurg Focus 25: E12, 2008.

3. Liu J, Liu Z, Zhang Z, Dong S, Zhen Z, Man L and Xu R: Internet usage for health information by patients with epilepsy in China Seizure 22: 787-790, 2013.

4. Tseng $\mathrm{CH}$, Huang WS, Muo $\mathrm{CH}$ and $\mathrm{Kao} \mathrm{CH}$ : Increased risk of epilepsy among patients diagnosed with chronic osteomyelitis. Epilepsy Res 108: 1427-1434, 2014.

5. Aliasgharpour M, Dehgahn Nayeri N, Yadegary MA and Haghani $\mathrm{H}$ : Effects of an educational program on self-management in patients with epilepsy. Seizure 22: 48-52, 2013.

6. Zhu H, Zhu J, Zhao T, Wu Y, Liu H, Wu T, Yang L, Zou Y, Zhang R and Zheng G: Alteration of interictal brain activity in patients with temporal lobe epilepsy in the left dominant hemisphere: A resting-state MEG study. Biomed Res Int 2014: 171487, 2014

7. Yeh CC, Wang HH, Chou YC, Hu CJ, Chou WH, Chen TL and Liao CC: High risk of gastrointestinal hemorrhage in patients with epilepsy: A nationwide cohort study. Mayo Clin Proc 88: 1091-1098, 2013.

8. Yao BZ, Yu SQ, Yuan H, Zhang HJ, Niu P and Ye JP: The role and effects of ANXA1 in temporal lobe epilepsy: A protection mechanism? Med Sci Monit Basic Res 21: 241-246, 2015.
9. Huang WX, Yu F, Sanchez RM, Liu YQ, Min JW, Hu JJ, Bsoul NB, Han S, Yin J, Liu WH, et al: TRPV1 promotes repetitive febrile seizures by pro-inflammatory cytokines in immature brain. Brain Behav Immun 48: 68-77, 2015.

10. Shetty AK and Hattiangady B: Concise review: Prospects of stem cell therapy for temporal lobe epilepsy. Stem Cells 25: 2396-2407, 2007.

11. Xiao Z, Peng J, Yang L, Kong $\mathrm{H}$ and Yin F: Interleukin-1 $\beta$ plays a role in the pathogenesis of mesial temporal lobe epilepsy through the PI3K/Akt/mTOR signaling pathway in hippocampal neurons. J Neuroimmunol 282: 110-117, 2015.

12. Zheng $\mathrm{H}$, Wang $\mathrm{X}$, Tang Z, Zheng W and Li Z: The PI3K/Akt and ERK1/2 signaling pathways mediate the erythropoietin-modulated calcium influx in kainic acid-induced epilepsy. Neuroreport 24: 335-341, 2013.

13. Peng $\mathrm{CH}$, Huang $\mathrm{CN}$ and Wang CJ: The anti-tumor effect and mechanisms of action of penta-acetyl geniposide. Curr Cancer Drug Targets 5: 299-305, 2005.

14. Yue PF, Zheng Q, Wu B, Yang M, Wang MS, Zhang HY, Hu PY and Wu ZF: Process optimization by response surface design and characterization study on geniposide pharmacosomes. Pharm Dev Technol 17: 94-102, 2012.

15. Song X, Zhang W, Wang T, Jiang H, Zhang Z, Fu Y, Yang Z, Cao Y and Zhang N: Geniposide plays an anti-inflammatory role via regulating TLR4 and downstream signaling pathways in lipopolysaccharide-induced mastitis in mice. Inflammation 37: 1588-1598, 2014.

16. Sardari S, Amiri M, Rahimi H, Kamalinejad M, Narenjkar J and Sayyah M: Anticonvulsant effect of Cicer arietinum seed in animal models of epilepsy: Introduction of an active molecule with novel chemical structure. Iran Biomed J 19: 45-50, 2015.

17. Szelenyi A, Joksimovic B and Seifert V: Intraoperative risk of seizures associated with transient direct cortical stimulation in patients with symptomatic epilepsy. J Clin Neurophysiol 24: 39-43, 2007.

18. Kibar AE, Unver O, Oflaz MB, Güven AS, Balli S, Ece I, Erdem S and Içağasıoğlu FD: Effect of antiepilepsy drug therapy on ventricular function in children with epilepsy: A tissue Doppler imaging study. Pediatr Cardiol 35: 280-288, 2014.

19. Chamberlain JM, Okada P, Holsti M, Mahajan P, Brown KM, Vance C, Gonzalez V, Lichenstein R, Stanley R, Brousseau DC, et al: Lorazepam vs diazepam for pediatric status epilepticus: A randomized clinical trial. JAMA 311: 1652-1660, 2014.

20. Solla DF, Paiva TS, André M and Paiva WS: Potential toxicity of dental nanomaterials to the central nervous system. Int J Nanomedicine 10: 5593-5594, 2015.

21. Payandemehr B, Khoshneviszadeh M, Varastehmoradi B, Gholizadeh R, Bahremand T, Attar H, Bahremand A and Dehpour AR: A COX/5-LOX inhibitor licofelone revealed anticonvulsant properties through iNOS diminution in mice. Neurochem Res 40: 1819-1828, 2015.

22. Per S, Tasdemir A, Yildirim M, Ayyildiz M, Ayyildiz N and Agar E: The involvement of iNOS activity in the anticonvulsant effect of grape seed extract on the penicillin-induced epileptiform activity in rats. Acta Physiol Hung 100: 224-236, 2013.

23. Cetin F, Yazihan N, Dincer S and Akbulut G: The effect of intracerebroventricular injection of beta amyloid peptide (1-42) on caspase-3 activity, lipid peroxidation, nitric oxide and NOS expression in young adult and aged rat brain. Turk Neurosurg 23: 144-150, 2013.

24. Zhang G, He JL, Xie XY and Yu C: LPS-induced iNOS expression in N9 microglial cells is suppressed by geniposide via ERK, p38 and nuclear factor- $\kappa \mathrm{B}$ signaling pathways. Int J Mol Med 30: 561-568, 2012.

25. McCown TJ, Knapp DJ and Crews FT: Inferior collicular seizure generalization produces site-selective cortical induction of cyclooxygenase 2 (COX-2). Brain Res 767: 370-374, 1997.

26. Tocco G, Freire-Moar J, Schreiber SS, Sakhi SH, Aisen PS and Pasinetti GM: Maturational regulation and regional induction of cyclooxygenase-2 in rat brain: Implications for Alzheimer's disease. Exp Neurol 144: 339-349, 1997.

27. Polascheck N, Bankstahl M and Löscher W: The COX-2 inhibitor parecoxib is neuroprotective but not antiepileptogenic in the pilocarpine model of temporal lobe epilepsy. Exp Neurol 224: 219-233, 2010. 
28. Shi Q, Cao J, Fang L, Zhao H, Liu Z, Ran J, Zheng X, Li X, Zhou Y, Ge D, et al: Geniposide suppresses LPS-induced nitric oxide, PGE2 and inflammatory cytokine by downregulating NF- $\kappa \mathrm{B}, \mathrm{MAPK}$ and AP-1 signaling pathways in macrophages. Int Immunopharmacol 20: 298-306, 2014.

29. Li DD, Feng ZH, Zhang WQ and Hong JS: The changes of AP-1 DNA binding activity and components in hippocampus of seizure-sensitive rat induced by kainate. Sheng Li Xue Bao 50 385-391, 1998

30. Gan AM, Butoi ED, Manea A, Simion V, Stan D, Parvulescu MM, Calin M, Manduteanu I and Simionescu M: Inflammatory effects of resistin on human smooth muscle cells: Up-regulation of fractalkine and its receptor, CX3CR1 expression by TLR4 and Gi-protein pathways. Cell Tissue Res 351: 161-174, 2013.

31. Dong M, Yang G, Liu H, Liu X, Lin S, Sun D and Wang Y: Aged black garlic extract inhibits HT29 colon cancer cell growth via the PI3K/Akt signaling pathway. Biomed Rep 2 : 250-254, 2014

32. Lee SH, Chun W, Kong PJ, Han JA, Cho BP, Kwon OY, Lee HJ and Kim SS: Sustained activation of Akt by melatonin contributes to the protection against kainic acid-induced neuronal death in hippocampus. J Pineal Res 40: 79-85, 2006

33. Guo LX, Liu JH and Yin F: Regulation of insulin secretion by geniposide: Possible involvement of phosphatidylinositol 3-phosphate kinase. Eur Rev Med Pharmacol Sci 18: 1287-1294, 2014.
34. Park JH, Yoon J, Lee KY and Park B: Effects of geniposide on hepatocytes undergoing epithelial-mesenchymal transition in hepatic fibrosis by targeting TGFbeta/Smad and ERK-MAPK signaling pathways. Biochimie 113: 26-34, 2015.

35. Tong Z, Jiang B, Wu Y, Liu Y, Li Y, Gao M, Jiang Y, Lv Q and Xiao X: MiR-21 protected cardiomyocytes against doxorubicin-induced apoptosis by targeting BTG2. Int J Mol Sci 16: 14511-14525, 2015

36. Chen Y, Chen H, Wu X, Wang X, Lin W and Yuan W: Comparative analysis of clinical outcomes between zero-profile implant and cages with plate fixation in treating multilevel cervical spondilotic myelopathy: A three-year follow-up. Clin Neurol Neurosurg 144: 72-76, 2016

37. Jackson RJ, Davis RJ, Hoffman GA, Bae HW, Hisey MS, Kim KD, Gaede SE and Nunley PD: Subsequent surgery rates after cervical total disc replacement using a Mobi-C Cervical Disc Prosthesis versus anterior cervical discectomy and fusion: a prospective randomized clinical trial with 5-year follow-up. J Neurosurg Spine 24: 734-745, 2016.

38. Zhang Y, Yin F, Liu J and Liu Z: Geniposide attenuates the phosphorylation of tau protein in cellular and insulin-deficient APP/PS1 transgenic mouse model of Alzheimer's disease. Chem Biol Drug Des 87: 409-418, 2016. 